\title{
Occurrence of Leptospira spp. and factors associated with the infection in horses from a military contingent in the Rio Grande do Sul State, Brazil
}

\section{Ocorrência de Leptospira spp. e fatores associados à infecção em equinos de contingente militar no estado do Rio Grande do Sul, Brasil}

\author{
Mariane Pacheco Bastiani ${ }^{1}$ (D); Luciane Teresinha Lovato ${ }^{1}$ (D); Ana Eucares von Laer $^{1}$ (D); Luciana Pötter ${ }^{1}$ (D); \\ Rogério Oliveira Rodrigues ${ }^{2}$ (D); Bianca Costabile de Souza ${ }^{2}$ (D); Geder Paulo Herrmann ${ }^{1}$ (D); \\ Luís Antonio Sangioni ${ }^{1}$ (D); Sônia de Avila Botton ${ }^{1}$ (D) \\ ${ }^{1}$ Universidade Federal de Santa Maria, Santa Maria - RS, Brazil \\ ${ }^{2}$ Instituto de Pesquisas Veterinárias Desidério Finamor, Eldorado do Sul - RS, Brazil
}

\begin{abstract}
The seroprevalence of Leptospira spp. and infection risk factors were investigated in horses from a military contingent in the Rio Grande do Sul State, Brazil. A total of 446 horses were evaluated and categorized into 309 mares, 11 stallions, and 126 horses with an average age of three years. To determine seroprevalence, serum samples from all horses were submitted to the microscopic agglutination test against 12 serovars belonging to nine serogroups, usually circulating in equine populations. To investigate the possible risk factors of infection by Leptospira spp., questionnaires were applied in that military unit. The seroprevalence in the horses with an average age of 3 years, mares, and stallions were 57.94\% (73/126), 54.05\% (165/309), and 45.45\% (5/11), respectively. The main risk factors identified were contact with different water sources, the presence of rodents, and contact with wild and domestic animals. The high seroprevalence of anti-Leptospira spp. antibodies may be associated with the presence of these risk factors. Therefore, the exposure of horses to possible reservoirs of Leptospira spp. should be minimized. Also, the immunoprophylaxis protocol should be reviewed and a shorter interval between vaccinations adopted to control leptospirosis in this herd.
\end{abstract}

Keywords: Leptospirosis. Abortion. Serologic tests. Risk factors. Horses.

\section{RESUMO}

A soroprevalência de Leptospira spp. e os fatores de risco para infecção foram investigados em cavalos de um contingente militar no Rio Grande do Sul, Brasil. Um total de 446 cavalos foram avaliados e categorizados em 309 éguas, 11 garanhões e 126 cavalos com idade média de três anos. Para determinação da soroprevalência, amostras de soro de todos os equinos foram submetidas ao teste de aglutinação microscópica contra 12 sorovares pertencentes a nove sorogrupos, normalmente circulantes em populações equinas. Para investigar os possíveis fatores de risco da infecção por Leptospira spp., foi aplicado um questionário naquela unidade militar. A soroprevalência nos cavalos com idade média de três anos, éguas e garanhões foi de 57,94\% (73/126), 54,05\% (165/309) e 45,45\% (5/11), respectivamente. Os principais fatores de risco identificados foram o contato com diferentes fontes de água, a presença de roedores e o contato com animais silvestres e domésticos. A alta soroprevalência de anticorpos anti-Leptospira spp. pode estar associada à presença desses fatores de risco. Portanto, a exposição destes equinos aos possíveis reservatórios de Leptospira spp. deve ser minimizada. Além disso, o protocolo de imunoprofilaxia deve ser revisto e, possivelmente, um menor intervalo entre as vacinas deve ser adotado para o controle da leptospirose neste plantel.

Palavras-chave: Leptospirose. Aborto. Diagnóstico sorológico. Fatores de risco. Cavalos. 
Correspondence to:

Sônia de Avila Botton

Universidade Federal de Santa Maria

Av. Roraima, 1000, Prédio 44, sala 5125, Campus Universitário

Camobi

CEP: 97105-900, Santa Maria, RS - Brazil

E-mail: sabott20@gmail.com

Received: January 12, 2021

Approved: May 25, 2021

How to cite: Bastiani MP, Lovato LT, von Laer AE, Pötter L, Rodrigues RO, Souza BC, Herrmann GP, Sangioni LA, Botton SA. Occurrence of Leptospira spp. and factors associated with the infection in horses from a military contingent in the Rio Grande do Sul State, Brazil. Braz J Vet Res Anim Sci. 2021;58:e180884. https://doi.org/10.11606/ issn.1678-4456.bjvras.2021.180884.

\section{Introduction}

Leptospirosis is a zoonotic infectious disease caused by bacteria of the genus Leptospira. The genus Leptospira is currently divided into 35 species classified into three phylogenetic clusters, which supposedly correlate with the virulence of the bacteria, being Leptospira interrogans, which is considered the most relevant. More than 200 serovars belonging to 23 serogroups are recognized. Each has its primary hosts, even though it may infect other species. This disease has a cosmopolitan distribution. In Brazil, however, it is an endemic disease that becomes epidemic in periods of high rainfall (Brasil, 2017; Silveira et al., 2017; Vincent et al., 2019; World Organisation for Animal Health, 2014).

Horses are susceptible to infection by a wide variety of Leptospira spp. serogroups with different serovars. However, the most prevalent serovars in equine leptospirosis are Australis, Autumnalis, Ballum, Bratislava, Canicola, Grippotyphosa, Hardjoprajitno, Icterohaemorrhagiae, Pomona, Pyrogenes, and Tarassovi. Infection in horses may be accompanied by clinical signs such as fever, jaundice and pulmonary hemorrhage. It may also result in abortion, stillbirth, and recurrent equine uveitis, which may progress to blindness. Leptospirosis is a common disease; however, it is probably underestimated because of the large number of chronically infected and asymptomatic animals. In equine species, this infection has been neglected. But the recognition that the disease can cause major economic losses, mainly because of abortion and blindness in animals of high zootechnical value, has attracted greater attention to this disease (Adler, 2015; Castro et al., 2011; Sousa et al., 2020).

According to Lasta et al. (2013) and Finger et al. (2014), the following factors may influence the seroprevalence of Leptospira spp.: access to different water sources, increased rainfall, flooding, presence of other animal species (domestic, wild, and synanthropic animals), deficiencies in sanitary management in a population, and favorable conditions that attract rodents. Environments containing stagnant water, moist soil, and decaying organic matter allow the bacteria to survive for up to 6 months (Adler, 2015; Brasil, 2017).

The prophylactic approach to minimize leptospirosis in animals is based on the use of vaccination in association with the control of environmental risk factors. Commercially available vaccines for Leptospira spp. include bacterins that are serovar-specific and induce short-term immunity. Vaccine tests performed on different animal species, such as sheep (Herrmann et al., 2011), cattle (Rodrigues et al., 2011), and equines (Martins et al., 2017) have demonstrated that antibodies produced in those vaccinated animals with bacterin vaccines for leptospirosis could not be detected using the microscopic agglutination test (MAT) for long periods after immunization. In horses, specifically, vaccinationinduced antibody titers have been shown to decline after 60 days of vaccination. Besides, these titers are difficult to detect using the MAT after 90 days (Martins et al., 2017).

Currently, the biggest challenge to immunity against Leptospira spp. infections are the development of immunobiological agents that promote broader and longer-lasting protection, by using a recombinant vaccine that can replace bacterins and/or the addition of autochthonous serovars (Silveira et al., 2017).

Military contingent horses represent an important sector of Brazilian horse breeding. These animals participate in different activities, such as military ceremonies, patrolling and guarding border areas and instruction camps, as well as in sports, such as dressage, jumping, full riding competition, and polo. Moreover, these horses are usually housed in stables with strict sanitary management and rigorous reproductive control (Campos et al., 2007).

This research was conducted in a military unit belonging to the Brazilian army, in the state of Rio Grande do Sul (RS), where the horses are destined for reproduction and sport. Although the health status of the animals in this establishment is a constant concern, there have been reports of the occurrence of abortions in mares, generating a concern with the health of the animals and a great economic impact on the herd. Thus, the objectives of this study were to determine the seroprevalence of Leptospira spp. in horses and to verify the risk factors of leptospirosis in that military unit.

\section{Material and Methods}

This research was conducted in a military unit, belonging to the Brazilian army, in the Rio Grande do Sul State (RS), Brazil. This unit breeds horses for reproduction and sports 
activities. The unit is located in the Southwest region where the climate is temperate, with four well-defined seasons and considerable rainfall throughout the year. The average temperature is $20.5^{\circ} \mathrm{C}$, and the average annual rainfall is $1.567 \mathrm{~mm}$ (Climate-Data.Org, 2019).

The study population comprised a total of 446 horses categorized into 309 mares, 11 stallions, and 126 horses with an average age of three years (female and males). Each category was grouped according to age and reproductive status, receiving different management procedures. Only the stallions were housed. The other animals were raised semi-extensively. The horses were kept in good sanitary conditions. Since sanitary control was provided to all animals, according to veterinary recommendations, quarantine was also practiced on animals newly arrived in the flock. The herd was regularly vaccinated, including for leptospirosis. This vaccine contained bacterins and was administered every six months.

In this establishment, abortions were reported in breeding mares. Besides leptospirosis, other agents have been investigated as a probable cause of equine abortion, including equine herpesvirus. However, the diagnosis for this agent was negative.

To confirm the suspicion of leptospirosis in the military unit, blood samples from 446 horses were sent to the following laboratories for leptospirosis diagnosis: Laboratory of Diagnosis and Research of Leptospirosis (LABLEPTO) at the Federal University of Santa Maria (UFSM) and Laboratory of Leptospirosis at the Institute of Veterinary Research Desidério Finamor (IPVDF). All blood samples were collected in 2018 six months after vaccination. However, in mares that required an urgent diagnosis because of the clinical signs of abortion, blood samples were collected around five months after vaccination. All serum samples were subjected to the microscopic agglutination test (MAT) using live antigens from Leptospira spp., including the serogroups Australis (Australis and Bratislava serovars), Ballum (Ballum serovar), Canicola (Canicola serovar), Grippotyphosa (Grippotyphosa serovar), Icterohaemorrhagiae (Copenhageni and Icterohaemorrhagiae serovars), Pomona (Pomona serovar), Pyrogenes (Pyrogenes serovar), Sejroe (Hardjo type Hardjoprajitno and Wolffi serovars), and Tarassovi (Tarassovi serovar), which were maintained in a selective medium for Leptospira spp., i.e., EMJH medium, according to the recommendations of World Organisation for Animal Health (2014).

For sample screening, previously diluted (1:50) sera were tested with bacterial antigens to analyze possible antigen-antibody reactions at a 1:100 dilution. Samples that showed $50 \%$ or more agglutination, detected using dark-field microscopy, were considered positive. For antibody titration, samples with agglutination activity were again tested against Leptospira spp. antigens using 1:100 to 1:3200 serial dilutions (World Organisation for Animal Health, 2014). The titer adopted as a cutoff point was 200 because of the endemic character of Leptospira spp. infection in tropical regions (Pinna et al., 2008; Siqueira et al., 2020) and to reduce the possible interference of vaccine titers on the seroprevalence in the studied population.

To investigate the possible risk factors that could act as potential facilitators for Leptospira spp. infection, questionnaires were applied to obtain information about individual characteristics of each animal category, including sanitary and management conditions, presence of rodents, contact with different water sources, the permanence of wetlands, contact with wild and domestic animals, presentation of clinical signs related to Leptospira spp. infection, and quarantine process for newly arriving horses.

The seroprevalence and frequency of anti-Leptospira agglutinins according to serovars were analyzed among all of the studied categories by using the Kruskal-Wallis test. When differences were found in this test, the means were compared using the Bonferroni test. The analyses were performed using the SAS statistical program, version 9.2 (SAS Institute, 2009).

This research was approved by the Animal Use Ethics Committee at UFSM (protocol number CEUA 8496030419).

\section{Results and Discussion}

In this study, 243 horses showed antibodies against Leptospira spp., with titers equal or superior to 200. The seroprevalence obtained in this herd was 54.48\% (243/446). Among the animal categories, the horses with an average age of three years, mares, and stallions showed seroprevalences of $57.93 \%$ (73/126), 53.39\% (165/309) and $45.45 \%(5 / 11)$, respectively. No difference was observed in the seroprevalences obtained in the different categories $(\mathrm{P}>0.05)$.

The blood samples tested were collected at six months (from stallions and horses with an average age of three years) and five months (from mares) after vaccination against Leptospira spp. The observed seroprevalence varied widely in previous research conducted in southern Brazil. In the state of Santa Catarina, Silva et al. (2020) and Farias et al. (2020) found $45.9 \%$ (273/595) and 45.4\% (94/207) of horses were positive for anti-Leptospira antibodies. And in the state of Paraná, the seroprevalence of 75.8\% (47/62) (Finger et al., 2014) were detected, while in RS, studies involving cart horses reported seroprevalences of $60 \%(75 / 125)$ in the city 
of Porto Alegre (Lasta et al., 2013) and 89.9\% (107/119) in Pelotas (Dewes, 2017). The animals tested in all these studies were non-vaccinated. Also, these animals generally presented lower titers than the minimum titer of 100 , which was the cutoff for a positive MAT. Although the present study population consisted of vaccinated horses, a considerable number of these animals (36/243) had antibody titers $\geq 800$, suggesting a possible recent contact with the pathogen.

Seroprevalence of anti-Leptospira spp. antibodies according to the serogroup/serovar were analyzed among the categories of horses (Table 1). In the categories of horses with an average age of three years and stallions, reactions to the Ballum serogroup/serovar were the most frequent, while in mares, the prevalence was of reactions to the Icterohaemorrhagiae serogroup (Icterohaemorrhagiae and Copenhageni serovars). However, reactions to the Australis serogroup (Australis and Bratislava serovars) was the second most prevalent in the horses an age of three years and mares, while reactions to the Icterohaemorrhagiae serogroup was the third most prevalent in the horses with a mean age of three years, and to the Tarassovi serogroup/serovar was the second more prevalent in the stallions. Wide reactivity to Leptospira spp. serovars tested were observed in all categories, especially in the mares, which demonstrated agglutinins against all evaluated serogroups/serovars.

Previous studies have shown a relationship among Leptospira spp. serovars and carrier species. Thus, the Bratislava serovar has been considered the most adapted in equine species (Adler, 2015). Serological reactions to this serovar have also been frequently detected in most epidemiological studies conducted on horses (Pinna et al., 2008, 2010; Siqueira et al., 2020). In the studied horse population, reactions to this serovar were detected in approximately $25 \%(61 / 243)$ of the blood samples and represented the fourth most prevalent serovar. However, if these results are analyzed in combination with those obtained against the Australis serovar, high reactivity to these two serovars (88/243) is observed. Since both serovars belong to the Australis serogroup (Bharti et al., 2003), we can infer this serogroup has a considerable prevalence (Table 1).

However, seroprevalence results for the Ballum serovar are less frequent, and it is rarely identified as the most prevalent serovar in equine studies. In a survey conducted by Lilenbaum (1998) in mares, this serovar had a seroprevalence of $7.24 \%$ (17/235). Another study, performed in Pelotas, RS, on cart horses found a seroprevalence of $36.1 \%$ (43/112) for the Ballum serovar (Dewes, 2017). In a study conducted in Chile, the reactions to Ballum serovar were the most frequent in a population of wagon horses. However, the same authors observed that the reactions to Autumnalis serovar was the most frequent among horses at military institutions (Tadich et al., 2016). Different Brazilian studies have shown a higher prevalence of serological reactions to the Icterohaemorrhagiae serovar. These studies were carried out in equine populations in the Brazilian states of São Paulo, Mato Grosso do Sul, Goiás (Langoni et al., 2004), Paraná (Finger et al., 2014), and the city of Porto Alegre, RS (Lasta et al., 2013).

The prevalent serovars may indicate the possible agent-maintaining hosts in each region. This information is relevant to the epidemiological understanding of leptospirosis

Table 1 - Seroprevalence of Leptospira spp. in equines from a military unit belonging to the Brazilian army, in Southwest of Rio Grande do Sul State, Brazil, 2018

\begin{tabular}{|c|c|c|c|c|c|c|c|}
\hline \multirow[b]{3}{*}{ Serogroup } & \multirow[b]{3}{*}{ Serovars } & \multicolumn{6}{|c|}{ Animal Category } \\
\hline & & \multicolumn{2}{|c|}{ Animals aged \pm 3 years } & \multicolumn{2}{|c|}{ Mares } & \multicolumn{2}{|c|}{ Stallions } \\
\hline & & $\begin{array}{l}\text { No of positive } \\
\text { reactions }\end{array}$ & $\begin{array}{c}\text { Prevalence } \\
\text { of serovar by } \\
\text { category }\end{array}$ & $\begin{array}{l}\text { No of positive } \\
\text { reactions }\end{array}$ & $\begin{array}{c}\text { Prevalence } \\
\text { of serovar by } \\
\text { category }\end{array}$ & $\begin{array}{l}\text { No }^{\circ} \text { of positive } \\
\text { reactions }\end{array}$ & $\begin{array}{c}\text { Prevalence } \\
\text { of serovar by } \\
\text { category }\end{array}$ \\
\hline \multirow[t]{2}{*}{ AUS } & AUS & 8 & $6.34 \%^{a}$ & 19 & $6.14 \% \%^{\mathrm{a}}$ & 0 & $0.00 \%^{\mathrm{a}}$ \\
\hline & BRA & 16 & $12.69 \%^{\mathrm{a}}$ & 45 & $14.56 \%{ }^{\mathrm{a}}$ & 0 & $0.00 \%^{\mathrm{a}}$ \\
\hline BAL & BAL & 36 & $28.57 \%^{\mathrm{a}}$ & 58 & $18.77 \%^{\mathrm{a}}$ & 4 & $36.36 \%^{\mathrm{a}}$ \\
\hline CAN & CAN & 4 & $3.17 \%^{a}$ & 29 & $9.38 \%{ }^{a}$ & 1 & $9.09 \%{ }^{a}$ \\
\hline GRI & GRI & 0 & $0.00 \% \%^{a}$ & 39 & $12.62 \%^{\mathrm{a}}$ & 1 & $9.09 \%^{a}$ \\
\hline \multirow[t]{2}{*}{ ICT } & COP & 0 & $0.00 \%^{\mathrm{a}}$ & 9 & $2.91 \%^{\mathrm{a}}$ & 0 & $0.00 \%^{\mathrm{a}}$ \\
\hline & $\mathrm{ICT}$ & 23 & $19.05 \%^{\mathrm{a}}$ & 58 & $18.77 \%^{\mathrm{a}}$ & 0 & $0.00 \%^{\mathrm{a}}$ \\
\hline POM & POM & 16 & $12.69 \%^{\mathrm{a}}$ & 50 & $16.18 \%^{\mathrm{a}}$ & 0 & $0.00 \%{ }^{\mathrm{a}}$ \\
\hline PYR & PYR & 8 & $6.34 \%^{a}$ & 18 & $5.82 \%^{\mathrm{a}}$ & 0 & $0.00 \%{ }^{\mathrm{a}}$ \\
\hline \multirow[t]{2}{*}{ SEJ } & HAR & 10 & $7.93 \% \%^{\mathrm{a}}$ & 22 & $7.11 \%^{\mathrm{a}}$ & 1 & $9.09 \%^{\mathrm{a}}$ \\
\hline & WOL & 0 & $0.00 \%^{a}$ & 12 & $3.88 \% \%^{a}$ & 0 & $0.00 \%^{a}$ \\
\hline TAR & TAR & 1 & $0.79 \%^{\mathrm{b}}$ & 22 & $7.12 \%^{b}$ & 3 & $27.27 \%^{a}$ \\
\hline
\end{tabular}

*Different letters in the line indicate difference by Bonferroni test $(\mathrm{P}<0.05)$. AUS: Australis; BRA: Bratislava; BAL: Ballum; CAN: Canicola; GRI: Grippotyphosa; ICT: Icterohaemorrhagiae; COP: Copenhageni; POM: Pomona; PYR: Pyrogenes; SEJ: Sejroe; HAR: Hardjo-prajitno; WOL: Wolff; TAR: Tarassovi. 
(Lasta et al., 2013). However, it must be emphasized that serological analyses may suggest but not definitively identify the infecting serovar, because there is evidence of cross-serological reactivity among Leptospira spp. serovars and serogroups. Thus, an animal infected with a serovar will develop antibodies against the infectious serovar, and these antibodies may cross-react with other serovars, albeit usually with lower MAT titers (World Organisation for Animal Health, 2014).

Notably, the highest prevalence of antibodies against the Ballum and Icterohaemorrhagiae serogroup was observed in the categories tested. Also, the highest titers were found against the Ballum serovar. Among the samples with titers $\geq 800,32 \%$ (15/47) of samples were against the Ballum serovar. Furthermore, these titers were detected in 19\% (9/47) of the samples that also reacted positively to the Icterohaemorrhagiae serovar. The detection of reactions to the Tarassovi serovar as the second most prevalent in the stallions is another relevant finding because this serovar is classified as a serovar of Leptospira borgpetersenii (Bharti et al., 2003). The consistency of these results justifies the discussion about the epidemiological aspects common to both serovars.

Rats and mice are described as the main hosts for the Ballum serovar, even though the infection has been described in wild animals, such as skunks, foxes, rabbits, and wild cats (Friedmann et al., 1973). The most frequent source of infection by the Icterohaemorrhagiae serovar is rodent contact, more specifically, contact with Rattus norvegicus, which is considered the main carrier of this serovar. Other reservoirs of this serovar are canines, swine, cattle, horses, sheep, and goats (Brasil, 2017; Langoni et al., 2004). The data presented in this study indicated that the presence of rodents and contact with wild animals were risk factors for the studied population. Thus, despite the possibility of cross-reaction among the serovars, the evidence suggests the involvement of the Ballum and Icterohaemorrhagiae serogroups in the studied horses.

Tadich et al. (2016) warned that despite the optimal sanitary conditions in the equine facilities of the military institution they studied, $23.31 \%$ of the animals had anti-Leptospira spp. antibodies. Moreover, studies have hypothesized that dogs may be the source of infection of Leptospira spp. Tarassovi serovar (Castro et al., 2011). Interestingly, stallions were the category with the highest seroprevalence against the Tarassovi serovar and this was the only category that had contact with dogs (information obtained through the questionnaire).

By applying the questionnaires, the main risk factors in the environment were identified that may have favored the maintenance and dissemination of the agent (Table 2). These included contact with different water sources and wetlands, the presence of rodents, and contact with wild and domestic animals (mainly cattle).

Notably, the horses with an average age of three years and mares were under a semi-extensive breeding regime, having contact with water sources and wetlands. Both categories sometimes shared pastures with cattle and had contact with rodents and wild animals. Farias et al. (2020) pointed out that the presence of different animal species occupying the same spaces suggests the environment as a determining factor in the infection epizootiology and variability of circulating serovars. The presence of rodents was also reported in the feed deposit of mares. Although rodent control measures are performed at the evaluated establishment, the complete elimination of these synanthropic animals is difficult, especially in rural properties. Among the three animal categories studied, the stallions were the least exposed to rodents and showed a lower prevalence of antibodies against the microorganism than did the other two categories. Also, confinement was identified as a risk factor specifically in the category of stallions. These horses,

Table 2 - Risk factors identified by the application of questionnaires in a military equine breeding unit, belonging to the Brazilian army, in the Southwest of Rio Grande do Sul State, Brazil, 2018

\begin{tabular}{lccc}
\hline \multicolumn{1}{c}{ Risk Factors } & & Categories of horses \\
\cline { 2 - 4 } $\begin{array}{l}\text { Stalled } \\
\text { Rodents in the feed depot }\end{array}$ & Mares & Animals aged \pm 3 years & Stallions \\
Contact with various water sources & & \\
Contact with wetlands & & \\
Contact with rodents & & \\
Contact with wild animals & & (cattle) \\
Contact with domestic animals & & \\
Presentation of ocular clinical signs & & \\
No quarantine on newly arrived animals & $6 / 9$ & $5 / 9$ \\
Presence of risk factors in the category & & & (dog) \\
\hline
\end{tabular}

Caption: The gray rectangle indicates the presence of the risk factor. The white rectangle indicates the absence of the risk factor. 
although stabled, sometimes had contact with dogs, as reported in the questionnaire.

In the evaluated property, reports of clinical signs associated with leptospirosis were cases of abortions and, through the questionnaire, the presence of ocular clinical signs was identified only in some animals in the three-year-old category. Both categories of mares and stallions did not show this clinical sign.

Although other causes of abortion may be present at this facility, the high seroprevalence of Leptospira spp. suggests this bacterium as a probable etiological agent of the reproductive problem in the evaluated herd. Even if horses were vaccinated every six months, the vaccination program may not have been effective in preventing abortion in the mares, because leptospirosis vaccines are suspensions of one or several inactivated serovars, which result in attenuated immunogenic activity (World Organisation for Animal Health, 2014). Additionally, the vaccines containing bacterins are the only commercial immunobiological agents currently available against Leptospira spp., and they induce short-term immunity, which is serovar-specific depending on the antigens contained in the vaccine (Silveira et al., 2017).

In regions with high seroprevalence and high rates of reproductive disorders, an important health management strategy is to shorten the interval between vaccinations (World Organisation for Animal Health, 2014). Another alternative would be the use of autochthonous vaccines containing Leptospira spp. isolates from the most prevalent serovars in a particular geographic region, since the immunity induced by vaccination, is specific to homologous serovars (Rodrigues et al., 2011; World Organisation for Animal Health, 2014).

Current vaccines have limited efficacy. Nevertheless, immunization against leptospirosis is important to control this infection. Also, decreasing contact with potential risk factors is fundamental to control the dissemination of the infectious agent in the environment and to susceptible

\section{References}

Adler B. Leptospira and Leptospirosis. Verlag Berlin Heidelberg: Springer; 2015.

Bharti AR, Nally JE, Ricaldi JN, Matthias AM, Diaz MM, Lovett MA, Levett PN, Gilman RH, Willig MR, Gotuzzo E, Vinetz JM. Leptospirosis: a zoonotic disease of global importance. Lancet Infect Dis. 2003;3(12):757-71. http:// dx.doi.org/10.1016/S1473-3099(03)00830-2. PMid:14652202. individuals (Pinna et al., 2008; World Organisation for Animal Health, 2014).

\section{Conclusion}

The evaluated equine population showed a high prevalence of antibodies against Leptospira spp., especially the Ballum and Icterohaemorrhagiae serogroups/serovars. The main risk factors identified were contact with different water sources, the presence of rodents and contact with wild and domestic animals. Consequently, the high seroprevalence of anti-Leptospira spp. antibodies may be associated with the presence of risk factors identified in this research. Therefore, the exposure of animals to possible reservoirs of Leptospira spp. infection must be minimized, and the immunoprophylaxis program reevaluated to reduce the interval between vaccinations to induce effective and long-lasting immunity in the herd.

\section{Conflict of Interest}

The authors declare that there are no conflicts of interest.

\section{Ethics Statement}

All procedures involving animals were approved by the Ethic Committee on Animal Use at Universidade Federal de Santa Maria (CEUA/UFSM), under protocol number CEUA 8496030419.

\section{Acknowledgments}

The authors thank the funding agencies: National Council for Scientific and Technological Development (CNPq), Coordination for the Improvement of Higher Education Personnel (CAPES) (financial code 001), Research Support Foundation of Rio Grande do Sul (FAPERGS), and Technology and Science Support Foundation (FATEC/UFSM). Additionally, we would like to thank the Brazilian Army for their important contribution to the research.

Brasil. Ministério da Saúde. Guia de Vigilância em Saúde [Internet]. 2. ed. Brasília: Ministério da Saúde, 2017. [cited 2019 Jan 12]. Available from: http://portalarquivos.saude.gov. br/images/pdf/2017/outubro /06/Volume-Unico-2017.pdf.

Campos VAL, McManus C, Fuck BH, Cassiano L, Pinto BF, Braga A, Louvandini H, Dias LT, Teixeira RA. Influência de fatores genéticos e ambientais sobre as características 
produtivas no rebanho eqüino do Exército Brasileiro. Rev Bras Zootec. 2007;36(1):23-31. http://dx.doi.org/10.1590/ S1516-35982007000100004.

Castro JR, Salaberry SRS, Souza MA, Lima-Ribeiro AMC. Sorovares de Leptospira spp. predominantes em exames sorológicos de caninos e humanos no município de Uberlândia, Estado de Minas Gerais. Rev Soc Bras Med Trop. 2011;44(2):217-22. http://dx.doi.org/10.1590/S003786822011005000012 . PMid:21468478.

Climate-Data.Org. Classificações [Internet]. 2019 [cited 2019 Jan 12]. Available from: https://pt.climate-data.org/ america-do-sul/brasil/rio-grande-do-sul-187/.

Dewes C. Estudos epidemiológicos da leptospirose equina na Região Sul do Rio Grande do Sul [dissertação]. Pelotas: Universidade Federal de Pelotas; 2017.

Farias DK, Dick G, Bunn S, Thaler A No, Rech C, Menin A, Saito ME. Risk factors related to seropositivity for Leptospira spp. in horses in the Serra Catarinense region. Cienc Rural. 2020. https://doi.org/10.1590/0103-8478cr20190483.

Finger MA, Barros Filho IR, Leutenegger C, Estrada M, Ullmann LS, Langoni H, Kikuti M, Dornbush PT, Deconto I, Biondo AW. Serological and molecular survey of Leptospira spp. among cart horses from an endemic area of human leptospirosis in Curitiba, Southern Brazil. Rev Inst Med Trop Sao Paulo. 2014;56(6):473-6. http://dx.doi.org/10.1590/ S0036-46652014000600003. PMid:25351539.

Friedmann CT, Spiegel EL, Aaron E, Mcintyre R. Leptospirosis ballum contracted from pet mice. Calif Med. 1973;118(6):512. PMid:4709528.

Herrmann GP, Rodrigues RO, Vidal CES, Machado G, Moreira ÉC, Leite RC. Curva de anticorpos pós-vacinais em ovinos imunizados com uma ou duas doses de bacterina oleosa anti-leptospirose, produzida com a sorovariedade Hardjo, tipo Hardjoprajitno, estirpe Norma, isolada no Brasil. Pesq Vet Bras. 2011;31(8):683-9. http://dx.doi. org/10.1590/S0100-736X2011000800009.

Langoni H, Da Silva AV, Pezerico SB, De Lima VY. Antileptospire agglutinins in equine sera, from São Paulo, Goias, and Mato Grosso do Sul, Brazil, 1996-2001. J Venom Anim Toxins Incl Trop Dis. 2004;10(3):207-18.

Lasta C, Oliveira S, Merini L, Dasso MG, Pedralli V, González FHD. Pesquisa de aglutininas anti-Leptospira em soros de equinos de tração em Porto Alegre, Brasil. R Bras Ci Vet. 2013;20(1):23-5. http://dx.doi.org/10.4322/rbcv.2014.051.

Lilenbaum W. Leptospirosis on animal reproduction: IV. Serological findings in mares from six farms in Rio de Janeiro, Brazil (1993-1996). Braz J Vet Res Anim Sci. 1998;35(2):613. http://dx.doi.org/10.1590/S1413-95961998000200002.

Martins G, Loureiro AP, Libonati H, Lilenbaum W. Humoral response in naturally exposed horses after leptospiral vaccination. J Equine Vet Sci. 2017;57:24-8. http://dx.doi. org/10.1016/j.jevs.2017.06.005.

Pinna M, Martins G, Freire I, Lilenbaum W. Seropositivity to Leptospira interrogans serovar Bratislava associated to reproductive problems without significant biochemical or haematological alteration in horses. Cienc Rural. 2010;40(10):2214-7. http://dx.doi.org/10.1590/S010384782010005000178 .

Pinna MH, Varges R, Lilenbaum W. Aplicação de um programa integrado de controle de leptospirose em equinos no Rio de Janeiro, Brasil. Rev Bras Cienc Vet. 2008;15(2):636. http://dx.doi.org/10.4322/rbcv.2014.199.

Rodrigues RO, Herrmann GP, Heinemann MB, Lage AP, Lopes LB, Moreira EC. Comparação entre a imunidade induzida em bovinos vacinados com bacterinas polivalentes comerciais e uma monovalente experimental. Pesq Vet Bras. 2011;31(1):10-6. http://dx.doi.org/10.1590/S0100736X2011000100002.

SAS Institute. Statistical Analysis System. SAS/STAT user guide, Version 9.2. Cary, NC: SAS Institute; 2009.

Silva AS, Jaguezeski AM, Laber IF, von Laer AE, Lovato LT, Silva MO, Moura AB. Leptospira spp. in horses in southern Brazil: seroprevalence, infection risk factors, and influence on reproduction. Comp Immunol Microbiol Infect Dis. 2020;73:101552. https://doi.org/10.1016/j.cimid.2020.101552.

Silveira MM, Oliveira TL, Schuch RA, McBride AJA, Dellagostin OA, Hartwig DD. DNA vaccines against leptospirosis: a literature review. Vaccine. 2017;35(42):42. http://dx.doi. org/10.1016/j.vaccine.2017.08.067. PMid:28882437.

Siqueira CC, Fraga DBM, Chagas-Junior AD, Athanazio DA, Silva MMN, Cerqueira RB, McBride FWC, Pinna MH, Ayres MCC. Seroprevalence and risk factors associated with equine leptospirosis in the metropolitan region of Salvador and Recôncavo Baiano region, Bahia state (NE 
Brazil). Trop Anim Health Prod. 2020:52:31-9. https://doi. org/10.1007/s11250-019-01956-5.

Sousa IKF, Silva RLC, Sousa RS, Vieira CEM, Melo S, Quevedo GP, Von Laer AE, Lovato LT, Tonin AA. Frequency of leptospirosis in horses in Manaus and metropolitan region in Amazonas State, Brazil. Braz J Vet Res Anim Sci. 2020;57(4):e172607. https://doi.org/10.11606/issn.16784456.bjvras.2020.172607.

Tadich TA, Tapia C, González D. Seroprevalence of Leptospira spp. in working horses located in the central region of Chile. J Equine Vet Sci. 2016;38:14-8. http://dx.doi.org/10.1016/j. jevs.2015.12.011.
Vincent AT, Schiettekatte O, Goarant C, Neela VK, Bernet E, Thibeaux R, Ismail N, Mohd Khalid MKN, Amran F, Masuzawa T, Nakao R, Amara Korba A, Bourhy P, Veyrier FJ, Picardeau M. Revisiting the taxonomy and evolution of pathogenicity of the genus Leptospira through the prism of genomics. PLoS Negl Trop Dis. 2019;13(5):1-25. http:// dx.doi.org/10.1371/journal.pntd.0007270. PMid:31120895.

World Organisation for Animal Health. Manual of diagnostic tests and vaccines for terrestrial animals [Internet]. 2014 [cited 2019 Jan 12]. Available from: http://www.oie.int/ standard-setting/terrestrial-manual/access-online/.

Financial Support: CAPES - financial code 001. 